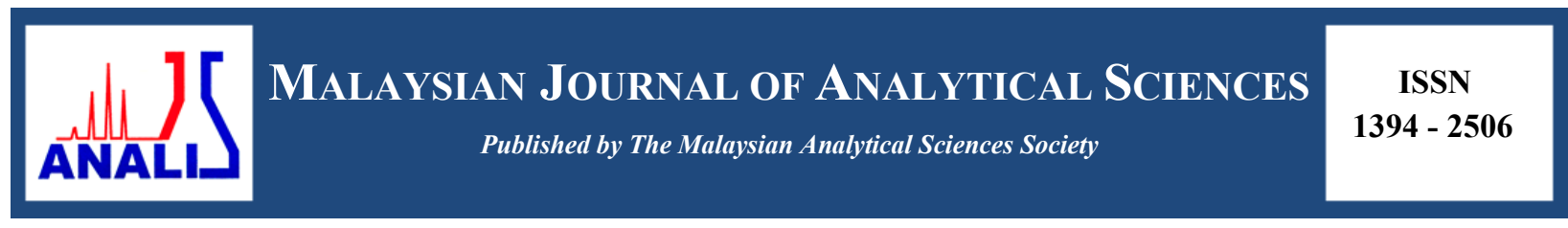

\title{
DEEP EUTECTIC SOLVENT AS A MEDIA IN SWELLING AND DISSOLUTION OF OIL PALM TRUNK
}

\author{
(Pelarut Eutektik Sebagai Media dalam Pembengkakan dan Pelarutan Batang Kelapa Sawit) \\ Emilia Abdulmalek $^{1,2 *}$, Syarilaida Zulkefli ${ }^{1}$, Mohd. Basyaruddin Abdul Rahman ${ }^{1,2}$ \\ ${ }^{1}$ Department of Chemistry, Faculty of Science \\ ${ }^{2}$ Enzyme and Microbial Technology Research, Faculty of Biotechnology and Biomolecular Science \\ Universiti Putra Malaysia, 43400 UPM Serdang, Selangor, Malaysia \\ *Corresponding author: emilia@upm.edu.my
}

Received: 17 August 2015; Accepted: 9 November 2016

\begin{abstract}
Pre-treatment is a crucial step in biomass processing prior to the hydrolysis or fermentation to bioethanol. Herein, the potential of deep eutectic solvent (DES) in the pretreatment of oil palm biomass were described. The mechanism of swelling and dissolution of oil palm trunk (OPT) was studied under optical microscopy. The OPT fibres were stirred and heated at $100{ }^{\circ} \mathrm{C}$ in choline chloride:glycerol (ChCl:Gly), choline chloride:ethylene glycol ( $\mathrm{ChCl}: \mathrm{EG})$, ethylammonium chloride:glycerol (EAC:Gly) and ethylammonium chloride:ethylene glycol (EAC:EG) with 1:2 molar ratio each. All DESs tested had showed homogenous swelling and disintegration of small fragments interaction mode with OPT. There were more small fragments observed in EACbased DES compared to ChCl-based DES. This finding supports the result for the percentage of dissolution where OPT in EACbased DES recorded higher dissolution with 55\% and 50\% in EAC:EG and EAC:Gly respectively whereas ChCl-based DES recorded only $33 \%$ and $29 \%$ in $\mathrm{ChCl}: \mathrm{EG}$ and $\mathrm{ChCl}$ :Gly, respectively. In ChCl-based DESs the fragmentations were accompanied by large unswollen section of fibres. The formation of small fragments indicates that the fibres experienced a fast dissolution. Therefore, the EAC-based DESs proved to be a better swelling and dissolution media for oil palm biomass pretreatment compared to ChCl-based DES.
\end{abstract}

Keywords: deep eutectic solvent, oil palm biomass, dissolution, swelling, pre-treatment

\begin{abstract}
Abstrak
Pra-rawat adalah satu langkah dalam pemprosesan biomas sebelum hidrolisis atau fermentasi kepada bioetanol. Disini, potensi pelarut eutektik (DES) dalam pra-rawat biomas kelapa sawit telah diterangkan. Mekanisma pembengkakan dan pemelarutan batang kelapa sawit (OPT) telah dikaji dengan mikroskop optik. Fiber OPT telah dikacau dan dipanaskan pada suhu $100{ }^{\circ} \mathrm{C}$ dalam kolin klorida:gliserol (ChCl:Gly), kolin klorida:etilin glikol (ChCl:EG), etilammonium klorida: gliserol (EAC:Gly) dan etilammonium klorida: etilin glikol (EAC:EG) dengan kadar molar 1:2 setiap satu. Semua DES yang dikaji telah menunjukkan mod interaksi pembengkakan secara setara dan pecahan fragmen kecil dengan OPT. Lebih banyak fragmen kecil dapat dilihat dalam DES berasaskan EAC berbanding dengan DES berasaskan $\mathrm{ChCl}$. Ini disokong oleh peratusan pelarutan dimana OPT dalam DES berasaskan EAC menunjukkan keputusan lebih tinggi dengan masing - masing 55\% dan 50\% dalam EAC:EG and EAC:Gly sementara DES berasaskan $\mathrm{ChCl}$ hanya menunjukkan masing - masing 33\% dan 29\% dalam ChCl:EG dan ChCl:Gly. Bagi DES berasaskan $\mathrm{ChCl}$, fragmentasi adalah disertai dengan kehadiran fiber besar yang tiada pembengkakan. Pembentukkan fragmen kecil menunjukkan bahawa fiber mengalami pelarutan yang cepat. Oleh itu, DES berasaskan EAC terbukti lebih baik sebagai media pembengkakan dan pelarutan bagi OPT berbanding DES berasaskan ChCl.
\end{abstract}

Kata kunci: pelarut eutektik, biomas kelapa sawit, pelarutan, pembengkakan, prarawat 


\section{Introduction}

Deep eutectic solvent (DES) is a new class of solvent that emerged from ionic liquid (IL) family which is formed by the combination of ammonium salt and a hydrogen bond donor [1]. The two components that have a high melting point each, for example choline chloride $\left(302{ }^{\circ} \mathrm{C}\right)$ and urea $\left(133^{\circ} \mathrm{C}\right)$, exhibit a freezing point depression of $12^{\circ} \mathrm{C}$, making it a liquid as a mixture at room temperature [2]. Various combinations of DES have been studied by changing the ammonium salt and the hydrogen bond donor. Examples of hydrogen bond donors used are alcohols, amides, carboxylic acids and amines [3]. Not only can the component be varied, the molar ratio of each component can also be varied. This widens the type of DES that can be formed. There are many advantages of DES including their biodegradability, thermal stability, low melting point and the fact that they are highly cost-efficient [1]. DES is easily prepared by simple mixing of the two selected substances, ammonium salt (e.g. choline chloride) and a hydrogen bond donor (e.g. glycerol), at $80{ }^{\circ} \mathrm{C}$ [4].

DES has shown considerably high potential in biocatalysis reactions such as hydrolysis, transesterification, and esterification. It was reported that choline chloride: glycerol (ChCl:Gly) as a co-solvent of aqueous reactions can enhance the reaction up to 20-fold [5]. The use of $10 \%(\mathrm{v} / \mathrm{v})$ of $\mathrm{ChCl}$ :Gly as the reaction medium for the hydrolysis of $p$-nitrophenyl acetate led to a 3-fold increase for pig liver esterase (PLE) and Rhizopusoryzae esterase (ROE) [5]. The properties and performance of DES in biocatalysis has led to our interest in exploring its utilization in dissolving high crystalline compounds such as lignocellulosic biomass in view of progressing with the enzymatic hydrolysis of the treated biomass.

Pre-treatment of biomass is crucial in order to break down the highly crystalline cellulose. The process will ease the access of cellulase to the amorphous cellulose, where this can enhance the conversion of monosaccharides (e.g. glucose). Francisco et al. [6] explored the application of the novel DES solvent system on lignocellulosic biomass. They reported that the solubility of lignin increased by the addition of lactic acid in DES, while cellulose gave negative results. However, a malic acid-proline series enhanced the dissolution of starch and cellulose. This report proved that the DES system or low transition temperature mixtures (LTTMs) can dissolve some of the lignin, although the screened mixtures gave low solubility for cellulose and starch.

Observation of the swelling and dissolution of fibre in certain solvents is one of the methods used to characterise the quality of solvents in terms of its ability to dissolve and swell the fibres. Many studies have been carried out for the dissolution of cellulose and wood fibre in various types of solvents such as $\mathrm{NaOH}$ [7], $N$-methylmorpholine- $N$ oxide (NMMO) [8], lithium chloride/urea/water [9] and ionic liquids [10-13]. The swelling process of cellulosic materials can improve the reactivity and accessibility of the cellulose. This phenomenon can be used to introduce activation of the substrate [14]. Five different modes were proposed for wood and cotton fibre dissolution as a function of solvent quality by using an NMMO-water system with or without additives [8].

Similar interactions were observed by using $\mathrm{NaOH}$-water and ionic liquids for various types of plant fibres and cellulosic materials. Cuissinat and Navard [8] had classified dissolution of wood and fibre into 5 different classes according to its degree of swelling or dissolution. The modes include fast dissolution by disintegration into fragments (Mode 1), swelling by ballooning with dissolution (Mode 2), swelling by ballooning without dissolution (Mode 3), homogenous swelling (Mode 4) and no swelling and no dissolution (Mode 5). In view of the advantages of DES over ionic liquid, an investigation of DES as a medium for biomass pre-treatment was conducted. This report is one of the earliest works on utilising DES for dissolving and pre-treatment of raw oil palm biomass. The properties of oil palm biomass fibre after pre-treament with DES were observed through optical microscopy.

\section{Preparation of OPT fibre}

\section{Materials and Methods}

OPT fibre was obtained from Biomass Technology Center (BTC) of Malaysian Palm Oil Board (MPOB). By using a thermo chemical refiner, the fibre was cleaned, shredded and refined into loose fibrous material. Prior to usage, the fibre was sieved to size $250 \mu \mathrm{m}$ and dried to constant weight. 


\section{Preparation of deep eutectic solvent}

DESs of 1:2 molar ratio (Table 1) were prepared by stirring the two components, ammonium salt and hydrogen bond donor (e.g.: $0.1 \mathrm{~mol}$ for $\mathrm{ChCl}$ and $0.2 \mathrm{~mol}$ for Gly), at a temperature of $80^{\circ} \mathrm{C}$. The mixture was stirred until a homogenous and colourless liquid was obtained [1].

Table 1. DESs used in the study

\begin{tabular}{lll}
\hline DES & Ammonium Salt & Hydrogen Bond Donor \\
\hline ChCl:Gly & Choline chloride & Glycerol \\
ChCl:EG & Choline chloride & Ethylene glycol \\
EAC:Gly & Ethylammonium chloride & Glycerol \\
EAC:EG & Ethylammonium chloride & Ethylene glycol \\
\hline
\end{tabular}

\section{Dissolution of oil palm biomass}

The samples were prepared by adding $0.5 \mathrm{~g}$ of fibre $(250 \mu \mathrm{m})$ into $9.5 \mathrm{~g}$ of DES in a screw capped vial. All mixtures were incubated in an oil bath at $100{ }^{\circ} \mathrm{C}$ with vigorous stirring. After 24 hours of incubation, a small amount of dissolution mixture was taken from each sample for observation. The swelling and dissolution mechanism was observed using an optical microscope with a Metallux 3 (Leitz) [(Nikon DS-Fil-42)]. A small portion of the dissolution mixture was placed on a glass plate and viewed at 20 times magnification.

\section{Percentage dissolution of oil palm trunk}

$5 \%$ of fibre $(250 \mu \mathrm{m})$ in DES was prepared by adding $0.5 \mathrm{~g}$ fibre in $9.5 \mathrm{~g}$ of DES. The mixture was incubated in oil bath at $100{ }^{\circ} \mathrm{C}$ with vigorous stirring. All dissolutions were carried out for 48 hours. After 48 hours, the mixture was centrifuged and filtered using crucible glass to separate the undissolved fibre. The filtration was washed with distilled water and dried in an oven at $50{ }^{\circ} \mathrm{C}$ overnight. Filtered sample was then cooled in desiccator and weighed to a constant weight. The percentage of fibre dissolved was calculated using equation 1 :

$$
\text { Fiber dissolved }(\%)=\frac{\underline{w}_{\underline{i}}-\underline{w}_{f}}{w_{i}} \times 100
$$

where $\mathrm{w}_{\mathrm{i}}$ is the weight of initial fibre and $\mathrm{w}_{\mathrm{f}}$ is the weight of residue recovered.

\section{Results and Discussion}

OPT was pre-treated in four different DESs (Table 1) in order to observe the type of interaction when the ammonium salt or hydrogen bond donor is varied. All data was taken within 24 hours for observation under optical microscopy. Figure 1 shows the shape of fibre observed in ChCl:Gly, ChCl:EG, EAC:Gly and EAC:EG after 24 hours of heating and stirring. Based on our observations, all DESs exhibited homogenous swelling and disintegration of small fragments for OPT fibres.

Homogenous swelling occurs when the solvent only swell the fibres and this does not lead to any dissolution of the fibres in the media. This type of interaction will make the fibre stay in the swollen state and thus leads to bad solvation for wood fibre as the swelling occurs very slowly. Cuissinat and Navard [8] suggested that in this type of behaviour, the solvent penetrates the fibre matrix at its loose regions such as pores and less dense disordered point, without making contact to the general part of the fibre. Unfortunately, this mode of interaction will not affect the cellulose crystal in dissolution or reformation to amorphous cellulose. 

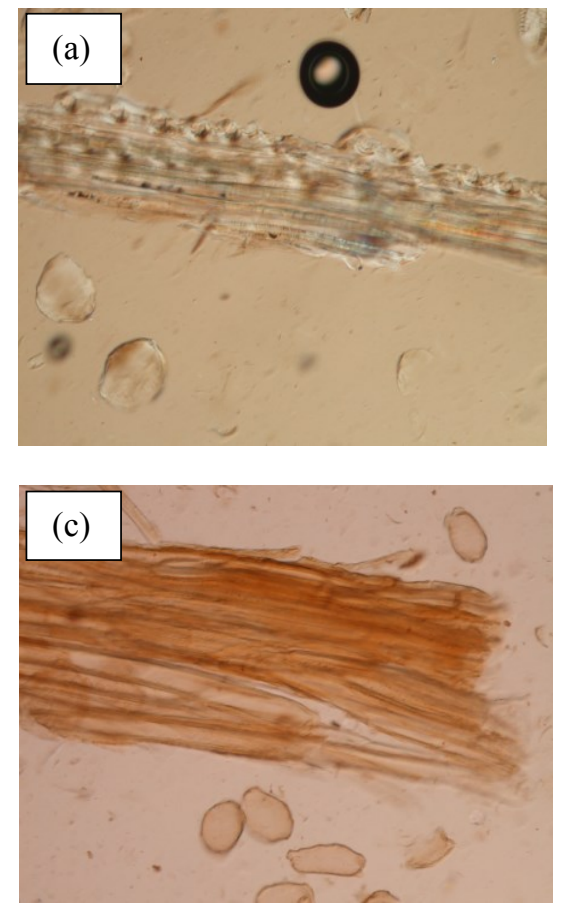
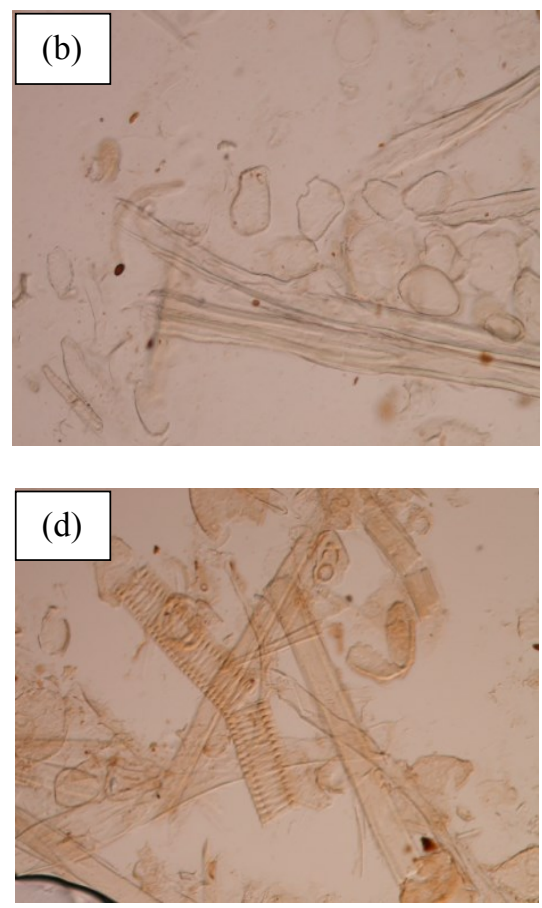

Figure 1. OPT in (a) ChCl:Gly, (b) ChCl:EG, (c) EAC:Gly and (d) EAC:EG after 24 hours at $100{ }^{\circ} \mathrm{C}$

Disintegration of small fragments of the fibres was another type of interaction observed in the sampling. This indicates fast dissolution where the fibres were broken over all their length, giving large rod-like pieces [8]. These small fragments will then easily dissolve in the media. Based on our data, this interaction is rather low in ChClbased DES but more frequent in EAC:Gly and EAC:EG (Figure 2). The presence of more small fragments in EACbased DES media showed that the solvent can provide good dissolution and thus indicates that they are better solvent compared to $\mathrm{ChCl}$ :Gly and $\mathrm{ChCl}$ :EG (Figure 3).
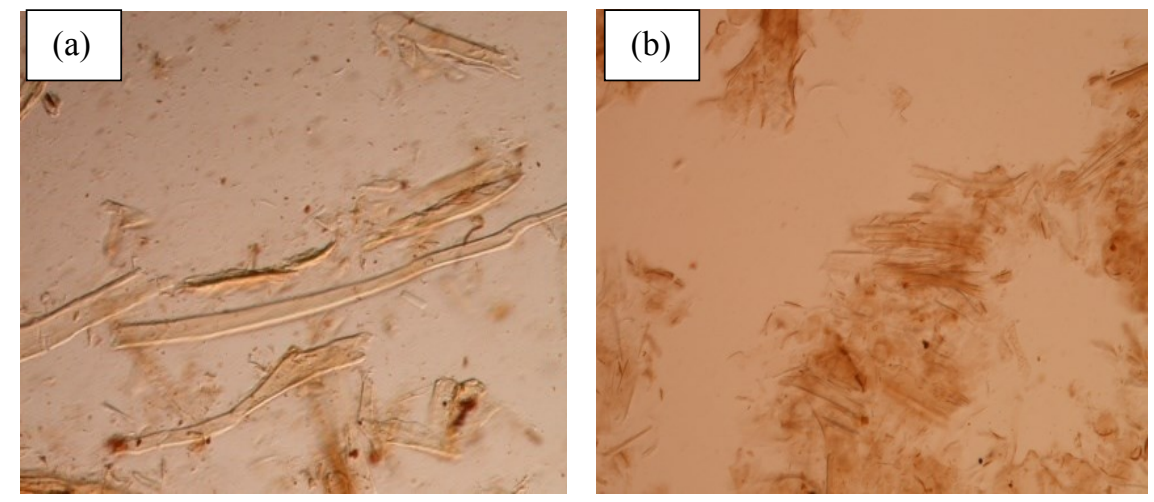

Figure 2. Fibre treated at $t=20$ hours in (a) EAC:Gly and (b) EAC:EG. Small fragments were generated mainly by agitation provided 

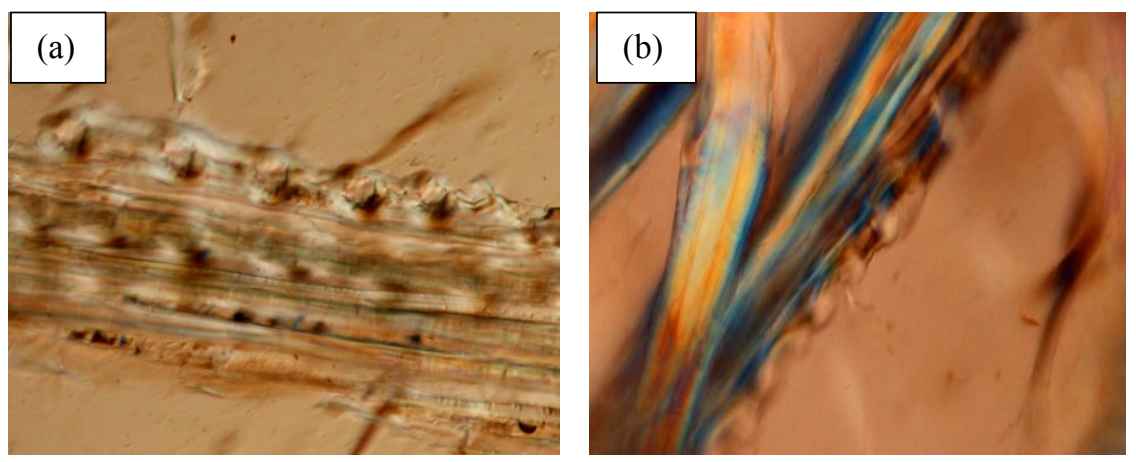

Figure 3. OPT fibre in (a) $\mathrm{ChCl}$ :Gly and (b) $\mathrm{ChCl}: \mathrm{EG}$ at $\mathrm{t}=24$ hours

In addition, the dissolution of OPT in each solvent were calculated. ChCl-based DES showed lower percentage of solubility than EAC-based DES (Table 2). This result clearly supports the earlier findings that EAC-based DES has higher capability in terms of dissolution of oil palm biomass. Figure 4 shows the chemical structure for $\mathrm{ChCl}$ and EAC. EAC has simpler structure compared to $\mathrm{ChCl}$ where $\mathrm{EAC}$ has only one alkyl chain. $\mathrm{ChCl}$ has three methyl groups attached to the nitrogen atom. Thus, $\mathrm{ChCl}$ only has one $\mathrm{H}$ that can make hydrogen bond with cellulose. EAC salt has $3 \mathrm{H}$ and ethyl chain attached to the nitrogen atom. This may help EAC-based DES to dissolve lignocellulosic materials better than ChCl-based DES.

Table 2. Percentage of dissolution for OPT in DESs after $48 \mathrm{hrs}$ of pre-treatment.

\begin{tabular}{lc}
\hline Solvent & Solubility (wt \%) \\
\hline ChCl:Gly & 33.27 \\
ChCl:EG & 29.13 \\
EAC:Gly & 50.77 \\
EAC:EG & 55.60 \\
\hline
\end{tabular}<smiles>C[N+](C)(C)CCO</smiles>

(a) Choline chloride

\section{$\mathrm{Cl}^{-}$}<smiles>CCCCCC</smiles>

(b) Ethylammonium chloride

Figure 4. Chemical structure of (a) choline chloride and (b) ethylammonium chloride

There are several other solvents that have been tested for mechanism of swelling and dissolution on wood fibres and cellulose derivatives. The solvents are $N$-methylmorpholine- $N$-oxide (NMMO), sodium hydroxide ( $\mathrm{NaOH}$ ) and ionic liquids (ILs). NMMO and $\mathrm{NaOH}$ are well known as conventional cellulose solvents. NMMO with small percentage of water $(17 \%$ and $35 \%)$ and $\mathrm{NaOH}$ showed excellent quality for wood and cellulose solvents [8]. Nitrocellulose in NMMO-water (17\% and 35\%) showed small fragmentation where the solvents give strong penetration and thus dissolves nitrocellulose in the media (Mode 1) [10]. 
ILs have been studied in order to offer alternative solvents for cellulose. The quality of ILs for wood and cellulose fibres can range from Mode 1 to Mode 4. 1-n-butyl-3-methylimidazolium chloride, $\mathrm{C}_{4}$ mimCl showed the best media for cotton and wood fibre with disintegration of small fragments and dissolves in $\mathrm{C}_{4}$ mimCl (Mode 1) [15]. 1-ethyl3-methylimidazolium chloride, EmimCl and 1-butyl-3-methylimidazolium chloride, BmimCl shows swelling by ballooning with dissolution occurred for cellulose fibre (Mode 2) [16]. Whereas for OPT, OPF and EFB fibres, both ILs exhibited homogenous swelling without dissolution. In this paper, we carried out the swelling and dissolution of OPT in DESs with aim to provide alternative solvent for wood and cellulose fibres. Based on our findings, DESs exhibited type of mechanism in Mode 1-4.

Although ILs and DESs have similarity in terms of quality, DESs have advantage in terms of solvent properties. ILs are hazardous due to the halide anions and very poor biodegradability. It requires high purity since small amount of impurity can affect its physical properties. The synthesis of ILs can't be described as an environmental friendly process since it requires large amount of salts and solvents in order to achieve complete anion exchange [17]. In contrast to ILs, DESs are cheaper, easier to synthesize and biodegradable [1]. Drawbacks of ILs lead DESs to be the alternative solvent for ILs and other conventional cellulose solvents.

Swelling and dissolution of wood fibre in DESs can be the easiest and fastest method in determining quality of solvents based on the modes introduced by Cuissinat and Navard [8], using simple instrument (optical microscopy) with low cost and less toxic solvent (DESs).

\section{Conclusion}

DESs were prepared and their effectiveness as pre-treatment media for oil palm biomass was studied under optical microscopy. DESs showed their potential as pre-treatment media for lignocellulosic biomass although currently its effectiveness has not surpassed some ILs. Based on our findings, DESs can provide homogeneous swelling and disintegration of small fragments for OPT fibres. The EAC-based DES showed better interaction than ChCl-based DES for dissolution of oil palm biomass. Currently, we are looking at the enzymatic hydrolysis of the DES pretreated oil palm biomass and preparing other DESs for the pre-treatment.

\section{Acknowledgement}

Authors would like to acknowledge the financial support given by the Graduate Research Fellowship (GRF), Universiti Putra Malaysia for this project.

\section{References}

1. Gorke, J. T., Srienc, F. and Kazlauskas, R. J. (2008). Hydrolase-catalyzed biotransformations in deep eutectic solvents. Chemical Communication, 10: 1235 - 1237.

2. Abbott, A. P., Boothby, D., Capper, G., Davies, D. L. and Rasheed, R. K. (2004). Deep eutectic solvents formed between choline chloride and carboxylic acid: versatile alternatives to ionic liquids. Journal of American Chemical Society, 126: $9142-9147$.

3. Nkuku, C. A. and LeSuer, R. J. (2007). Electrochemistry in deep eutectic solvents. Journal of Physical Chemistry B, 111(46), 13271 - 13277.

4. Zhao, H., Baker, G. A. and Holmes, S. (2011). New eutectic ionic liquids for lipase activation and enzymatic preparation of biodiesel. Organic \& Biomolecular Chemistry, 9(6): 1908 - 1916.

5. Lindberg, D., Revenga, M. and Widersten, M. (2010). Deep eutectic solvents (DESs) are viable cosolvents for enzyme-catalyzed epoxide hydrolysis. Journal of Biotechnology, 147: 169 - 171.

6. Francisco, M., Bruinhorst, A. and Kroon, M. C. (2012). New natural and renewable low transition temperature mixtures (LTTMs): screening as solvents for lignocellulosic biomass processing. Green Chemistry, 14 (8): $2153-2157$.

7. Moigne, N. and Navard, P. (2010). Dissolution mechanism of wood cellulose fibres in NaOH/water. Cellulose, 17(1): $31-45$.

8. Cuissinat, C. and Navard, P. (2006) Swelling and dissolution of cellulose part I: Free floating cotton and wood fibres in $N$-Methylmorpholine- $N$-oxide-water mixtures. Macromolecular Symposium, 244: 1 - 18. 
9. Tatárová, I., Manian, A. P., Široká, B. and Bechtold, T. (2010). Nonalkali swelling solutions for regenerated cellulose. Cellulose, 17(5), $913-922$.

10. Cuissinat, C., Navard, P. and Heinze, T. (2008). Swelling and dissolution of cellulose, Part V: Cellulose derivatives fibres in aqueous systems and ionic liquid. Cellulose, 15(1): $75-80$.

11. Swatlotski, R. P., Spear, S. K., Holbrey, J. D. and Rogers, R. D. (2002). Dissolution of cellulose with ionic liquids. Journal of American Chemical Society, 124(18): 4974 - 4975.

12. Vancov, T., Alston, A-S., Brown, T. and McIntosh, S. (2012). Use of ionic liquid in converting lignocellulosic material to biofuels. Renewable Energy, 45: $1-6$.

13. Zhu, S., Wu, Y., Chen, Q., Yu, Z., Wang, C., Jin, S., Ding, Y. and Wu, G. (2006). Dissolution of cellulose with ionic liquids and its application:a mini review. Green Chemistry, 8(4), 325 - 327.

14. Kunze, J. and Fink, H. P. (2005). Structural changes and activation of cellulose by caustic soda solution with urea. Macromolecular Symposium, 223: 175 - 187.

15. Cuissinat, C., Navard, P. and Heinze, T. (2008). Swelling and dissolution of cellulose. Part IV: Free floating cotton and wood fibres in ionic liquids. Carbohydrate Polymers, 72(4): 590 - 596.

16. Abdul Rahman, M. B., Ishak, Z. I., Abdullah, D. K., Aziz, A. A., Basri, M. and Salleh, A.B. (2012). Swelling and dissolution of oil palm biomass in ionic liquids. Journal of Oil Palm Research, 24: $1267-1276$.

17. Zhang, Q., Vigier, K. D. O., Royer, S. and Jerome, F. (2012). Deep eutectic solvents: Syntheses, properties and applications. Chemical Society Reviews, 41(21): 7108 - 7146. 